\title{
Secondary Stress Response of Nile Tilapia, Oreochromis niloticus, After Direct Transfer to Different Salinities*
}

\author{
Ayşe KARŞI $\quad$ Hijran YAVUZCAN YILDIZ ${ }^{1}$
}

Geliş Tarihi: 18.10.2004

\begin{abstract}
The secondary stress response of Nile tilapia, Oreochromis niloticus after direct transfer to saline water was evaluated assessing the levels of hematocrit, plasma glucose, sodium, potassium, chloride and calcium. Fish were transferred directly from freshwater to two experimental salinity (9 and $18 \mathrm{ppt}$ ) for 72 hours. Plasma glucose, $\mathrm{Na}^{+}, \mathrm{K}^{+}, \mathrm{Cl}^{-}$ and $\mathrm{Ca}^{++}$all increased however, hematocrit did not change throughout the 3 days exposure period. Considering the parameters measured in this study Nile tilapia appeared to exhibit a stress response to direct transfer to saline water, nevertheless, the magnitude of stress response was related to salinity level.
\end{abstract}

Key Words: Tilapia, Oreochromis niloticus, saline water, secondary stress

\section{Tilapianın, Oreochromis niloticus Farklı Tuz Konsantrasyonlarındaki Sulara Direkt Transferinde Oluşan Sekonder Stres Yanıtı}

\begin{abstract}
Öz: Tilapianın, Oreochromis niloticus tuzlu suya direkt olarak transfer edilmesi durumunda gelişen sekonder stres yanıtı hematokrit, plazma glukoz, sodyum, potasyum, klorid ve kalsiyum ölçümleri ile değerlendirilmiştir. Balıklar doğrudan iki farklı deneysel tuzluluğa (9 ve $18 \mathrm{ppt}) 72$ saatlik bir periyotta maruz bırakılmışlardır. Incelenen parametrelerden plazma glukoz, plazma $\mathrm{Na}^{+}, \mathrm{K}^{+}, \mathrm{Cl}^{-}$ve $\mathrm{Ca}^{++}$deney süresince artış gösterirken hematokrit değerleri değişmemiştir. Bu çalışmada değerlendirilen parametreler gözönüne alındığında tilapianın tuzlu suya direkt transferinin strese neden olduğu, ancak stres yanıtının büyüklüğünün tululuk seviyesi ile ilgili olduğu belirlenmiştir
\end{abstract}

Anahtar Kelimeler: Tilapia, Oreochromis niloticus , tuzlu su, sekonder stres

\section{Introduction}

Fish belonging to the genus Oreochromis (formerly Sarotherodon) tolerate a wide variety of environmental conditions (acidity, salinity, temperature, poor quality water, etc.) and show high growth and reproductive rates that make them very suitable for culture (Avella et al. 1993). Increasing demands on the use of freshwater for agricultural, industrial and domestic purposes progressively limit freshwater-based aquaculture. The efficient uses of marine and brackish environments for aquaculture becomes a vital alternative (Suresh and Lin 1992). It has been widely suggested that the euryhaline tilapias could be cultured in higher salinity of brackishwater and marine systems, thereby enabling their exploitation in arid lands and coastal areas (Watanabe et al. 1985). Many species of tilapia are euryhaline, but the tolerance limits of species vary considerably (Suresh and Lin 1992). T.nilotica survived after direct transfer to $50 \%$ seawater (17,5 ppt), but not $75 \%$ seawater (Stickney 1986).

Hormones, such as catecholamines, glucagon, prolactin, and cortisol are believed to regulate the entire acclimation process (Suresh and Lin 1992). Stress in fish has been shown to cause a primary response, involving neuro-hormonal stimulation, resulting in an increase in corticosteroid and catecholamine secretions. In turn, these primary effects cause a number of physiological changes known as 'secondary effects' (Foo and Lam 1993).
Studies involving tilapia in saline waters include basic research on the physiology of salinity stress in fish as well as more practical research on aquacultural practices. Stress response of tilapia due to saline water exposure has not received a great deal of attention.

The objective of this study was to evaluate the secondary stress response of Nile tilapia after direct transfer to different salinities (9 and $18 \mathrm{ppt}$ ) in a shortterm.

\section{Materials and Methods}

One hundred and twenty Nile tilapia, $O$. niloticus with a mean body weight of $67.36 \pm 17.68 \mathrm{~g}$ obtained from Ankara University, Fisheries Unit of Aquaculture and Fisheries Department were used in this study. Fish $(n=40$ for each treatment) were transferred directly from freshwater to two different experimental salinities; 9 and 18 ppt. Control fish were also transferred from freshwater to freshwater. Fish were maintained for 72 hours in experimental salinities and then sampled.

Fish were held in the fiberglass tanks containing 200 I water at a stocking density of 20 fish/a tank. Water of different salinities was prepared by mixing tap water and

\footnotetext{
This article was produced from MSc Thesis

${ }^{1}$ Ankara Üniv.Ziraat Fak. Su Ürünleri Bölümü-Ankara
} 
Instant Ocean artificial sea salts. Water temperature during the experiment was maintained at $24^{\circ} \mathrm{C}$.

Blood samples were drawn by cardiac puncture into heparinized syringes. The blood was centrifuged for $7 \mathrm{~min}$ at $3300 \mathrm{rev} . / \mathrm{min}$. and the plasma was removed. Fish were not anaesthetized before bleeding. Plasma glucose, $\mathrm{Ca}^{++}$, $\mathrm{Cl}^{-}$were measured using assay kits prepared by Labkit (Barcelona, Spain) with a Boehringer 4010 spectrophotometer. Plasma $\mathrm{Na}^{+}$and $\mathrm{K}^{+}$were determined using Hitachi 911 instrument. Hematocrit measurements were made immediately by drawing samples of blood into heparinized capillary tubes and centrifuging at 12500 r.p.m. for 4 min (Siwicki and Anderson 1993).

One-way ANOVA was used to determine differences among the treatment groups for each blood analyte. When a significant $(p<0.05)$ difference was detected, the means were compared by use of Duncan's multiple range test.

\section{Results}

Nile tilapia (O. niloticus) could tolerate direct transfer from freshwater to 9 and 18 ppt salinities for 72 hours. No fish in any of the treatment group died when placed in different salinities. However, Nile tilapia in general, could not maintain hydromineral balance during the experimental period. Mean values of blood parameters of fish transferred directly from freshwater to different salinities (9 and $18 \mathrm{ppt)}$ of sea water for 72 hours are shown in Table 1. In fish transferred to 9 ppt salinity for 72 $\mathrm{h}$ hematocrit remained unchanged when compared to control group $(p>0.05)$. Plasma glucose concentration exhibited only a small increase however, plasma $\mathrm{Cl}^{-}, \mathrm{Na}^{+}$, $\mathrm{K}^{+}$and $\mathrm{Ca}^{++}$increased significantly $(\mathrm{p}<0.05)$. Following transfer direct from freshwater to $18 \mathrm{ppt}$ salinity at 72 hours all parameters except hematocrit were higher than those of control $(p<0.05)$. The mean values of plasma parameters measured in the treatment groups, increased with increasing salinity, among the treatment groups only plasma $\mathrm{K}^{+}$values did not vary significantly $(p>0.05)$, however, plasma $\mathrm{K}^{+}$values of fish from both groups were higher than that control of freshwater tilapia $(p<0.05)$.

\section{Discussion}

The stress response of Nile tilapia to increased salinity was evaluated using the levels of hematocrit, plasma glucose, $\mathrm{Na}^{+}, \mathrm{K}^{+}, \mathrm{Ca}^{++}$and $\mathrm{Cl}^{-}$as indicators. Secondary stress might be indicated by a significant decrease or increase in some biochemical variables in the blood. Changes at this level can reflect loss of homeostasis (e.g. decreased blood electrolytes) and demonstrate a compensatory response (e.g. elevated blood glucose) as reported by Schreck (1990). Thus, primary stress response includes increased production of catecholamines and cortisol and a partial stress response emphasizing either catecholamines or cortisol. Responses to disruptions of homeostasis due to the effects of catecholamines and cortisol released during primary response are presented in the blood parameters as secondary responses (Smith 1991, Pickering 1992).
Table 1. Mean \pm SE and the range values for selected secondary stress indices of Nile Tilapia after direct transfer to 9 and $18 \mathrm{ppt}$ for $72 \mathrm{~h}$

\begin{tabular}{|c|c|c|c|}
\hline \multirow[t]{2}{*}{ Parameters } & \multirow[t]{2}{*}{ Control } & Salinity Level & \multirow[b]{2}{*}{$18 \mathrm{ppt}$} \\
\hline & & $9 p p t$ & \\
\hline $\begin{array}{l}\text { Hematocrit (\%) } \\
\text { (min-max) }\end{array}$ & $\begin{array}{l}10.19 \pm 1.55^{a^{*}} \\
(7.54-22.00)\end{array}$ & $\begin{array}{l}11.09 \pm 1.12^{a} \\
(7.84-19.60)\end{array}$ & $\begin{array}{c}9.19 \pm 0.46^{\mathrm{a}} \\
(7.50-11.66)\end{array}$ \\
\hline $\begin{array}{c}\text { Plasma } \\
\text { glucose }(\mathrm{mg} / \mathrm{dl}) \\
\text { (min-max) }\end{array}$ & $\begin{array}{c}94.87 \pm 0.22^{\mathrm{ab}} \\
(94-96)\end{array}$ & $\begin{array}{c}97.87 \pm 0.69^{b} \\
(95-101)\end{array}$ & $\begin{array}{c}120.37 \pm 0.26^{\mathrm{a}} \\
(119-121)\end{array}$ \\
\hline $\begin{array}{c}\text { Plasma } \mathrm{Cl}^{-} \\
(\mathrm{mmol} / \mathrm{l}) \\
(\mathrm{min}-\mathrm{max})\end{array}$ & $\begin{array}{c}136.62 \pm 0.18^{\mathrm{C}} \\
(136-137)\end{array}$ & $\begin{array}{c}152.00 \pm 0.26^{b} \\
(151-153)\end{array}$ & $\begin{array}{c}188.25 \pm 0.411^{a} \\
(187-190)\end{array}$ \\
\hline $\begin{array}{c}\text { Plasma Na } \\
(\mathrm{mmol} / \mathrm{l}) \\
(\mathrm{min}-\mathrm{max}) \\
\end{array}$ & $\begin{array}{c}165.00 \pm 0.53^{\mathrm{C}} \\
(163-167)\end{array}$ & $\begin{array}{c}176.87 \pm 0.22^{b} \\
(176-178)\end{array}$ & $\begin{array}{c}210.25 \pm 0.45^{\mathrm{a}} \\
(209-212)\end{array}$ \\
\hline $\begin{array}{c}\text { Plasma K } \\
(\mathrm{mmol} / \mathrm{l}) \\
(\mathrm{min}-\mathrm{max})\end{array}$ & $\begin{array}{c}4.80 \pm 0.02^{b} \\
(4.7-4.9)\end{array}$ & $\begin{array}{c}5.13 \pm 0.018^{a} \\
(5.1-5.2)\end{array}$ & $\begin{array}{l}5.15 \pm 0.018^{a} \\
\quad(5.1-5.2)\end{array}$ \\
\hline $\begin{array}{c}\text { Plasma Ca++ } \\
(\mathrm{mg} / \mathrm{dl}) \\
(\mathrm{min}-\mathrm{max})\end{array}$ & $\begin{array}{c}7.34 \pm 0.029^{c} \\
(7.34-7.36)\end{array}$ & $\begin{array}{c}7.68 \pm 0.069^{b} \\
(7.65-7.70)\end{array}$ & $\begin{array}{l}9.34 \pm 0.012^{\mathrm{a}} \\
(9.30-9.40)\end{array}$ \\
\hline
\end{tabular}

* Different letters in a row refers significant differences between the control and the treatment groups $(p<0.05)$.

The salinity levels of 9 and 18 ppt did not influence hematocrit values. Hemoconcentration has been observed in some teleost fishes as a response to acute stress (Iwama et al. 1993). In the present study, there is no evidence of hemoconcentration occurring in the Nile tilapia exposed to 9 and 18 ppt salinity.

In this study the plasma glucose levels in the tilapia exposed to $18 \mathrm{ppt}$ salinity for 72 hours were relatively high when compared to control and the fish exposed to 9 ppt salinity. The plasma glucose level of the fish exposed to 9 ppt saline water was similar to control. The high plasma glucose in seawater adapted tilapia, Saratherodon melanotheron was also observed by Lea Master et al. (1990). Hyperglycemia is an expected result of stress or exhaustive excercise in fishes (Barton and Iwama 1991; Hrubec et al. 1997). Blood glucose levels may elevated immediately by catecholamines thus; in the present study increases observed in the group of 18 ppt salinity may be the result of corticosteroids, which facilitate gluconeogenesis, as stated by Barton and Iwama (1991). It is known that the degree of hyperglycemia may change depending on the type of stress and the sampling times (Rotlland et al. 1997). In the fish exposed to 9 ppt salinity slight increase in plasma glucose level is possibly related to relatively lower salinity.

Stress leads to a hydromineral imbalance (Mazeaud et al. 1977) and rectification of the stress-related osmotic dysfunction places an energetic load on the fish. (Schreck, 1990). In addition, electrolytes serve as a general measure of osmoregulatory dysfunction (Robertson et al. 1987). In the present study, electrolytes of the treatment groups had a marked deviation from the control values, however, plasma $\mathrm{K}^{+}$values did not vary between the experimental groups. Plasma $\mathrm{Cl}^{-}$and $\mathrm{Na}^{+}$values increased 
with increasing salinity. Recovered or unstressed fish should have plasma $\mathrm{Na}^{+}$levels of rested, healthy animals. In this study plasma $\mathrm{Na}^{+}$values of the experimental groups may not be representative of unstressed state. Plasma $\mathrm{Ca}^{++}$concentration of control was lower than the experimental groups. As well as that increases in plasma $\mathrm{Na}^{+}, \mathrm{K}^{+}$and $\mathrm{Cl}^{-}$values have been reported in tilapia, $S$. melanotheron that have adapted from freshwater to seawater (Lea Master et al. 1990).

Finally, it seems that Nile tilapia under direct transfer to saline water elicit stress response associated with changing blood characteristics. Considering the values of the stress indicators measured in this study the magnitude of stress response may be related to the salinity level.

\section{Conclusion}

Pre-acclimation of Nile tilapia at low salinity and gradual transfer to higher salinities may diminish the magnitude of stress response.

\section{References}

Avella, M., J. Berhaut and M. Bornancin. 1993. Salinity tolerance of two tropical fishes, Oreochromis aureus and Oreochromis niloticus. I. Biochemical and morphological changes in the gill epithelium. Journal of Fish Biology 42 243-254.

Barton, B. A. and G. K. Iwama. 1991. Physiological changes in fish from stress in aquaculture with emphasis on the response and effects of corticosteroids. Annual Review of Fish Diseases 1:3-26.

Foo, J. T. W. and T. J. Lam. 1993. Serum cortisol response to handling stress and the effect of cortisol implantation on testosterone level in tilapia, Oreochromis mossambicus. Aquaculture 115: 145-158

Hrubec, T. C., J. L. Robertson and S. A. Smith. 1997. Effects of temperature on hematologic and serum biochemical profiles of hybrid striped bass (Morone chrysops x Morone saxatilis).The American Journal of Veterinary Research 58 : 126-130.

Iwama, G. K., J. C. McGeer and M. P. Pausluk. 1993. The effects of five fish anaesthetics on acid-base balance, hematocrit, blood gases, cortisol and adrenaline in rainbow trout. Canadian Journal of Zoology 67: 2065-2073.
Lea Master, B. R., J. A. Brach, R. S. Fujico and R. M. Nakamura. 1990. Hematologic and blood chemistry values for Sarotherodon melanotheron and a red hybrid tilapia in freshwater and seawater. Comparative Biochemistry and Physiology 97A: 525-529.

Mazeaud, M. M., F. Mazeaud and E. M. Donaldson. 1977. Primary and secondary effects of stress in fish: some new data with a general review. Trans. American Fisheries Society 106: 201-212.

Pickering, A. D. 1992. Rainbow trout husbandry: management of the stress response. Aquaculture 100: 125-139.

Robertson, L., P. Thomas, C. R. Arnold and J. M.Trant. 1987. Plasma cortisol and secondary stress response of red drum to handling, transport, rearing density, and a disease outbreak. The Progressive Fish-Culturist 49 (1): 1-13.

Rotllant, J., M. Pavlidis, M. Kentouri, M. E Abad and L. Tort. 1997. Non-specific immune responses in the red porgy Pagrus pagrus after crowding stress. Aquaculture 156: 279-290.

Schreck, C. B. 1990. Physiological, behavioral and performance indicators of stress. In: Biological indicators of stress in fish, (Ed. by S. M. Adams) American Fisheries Symposium 8, Bethesda, Maryland. 29-37.

Siwicki, A. K. and D. P. Anderson, 1993. Immunostimulation in fish. In: Proceedings of the Nordiac Symposium on Fish Immunology, 19-22 May, Sweden.

Smith, S. L. 1991. Introduction to fish physiology. Argent Lab., Redmond, WA, USA. 352 p.

Stickney, R. R. 1986. Tilapia tolerance of saline waters: a review, The Progressive Fish Culturist 48:161-167.

Suresh, A. V. and C. K. Lin. 1992. Tilapia culture in saline waters: a review. Aquaculture 106: 201-226.

Watanabe, W. O., C. M. Kuo and M. C. Huang. 1985. Salinity tolerance of Nile Tilapia fry (Oreochromis niloticus), spawned and hatched at various salinities. Aquaculture 48:159-176.

\section{İletişim adresi:}

Hijran YAVUZCAN YILDIZ

Ankara Üniv. Ziraat Fak. Su Ürünleri Bölümü-Ankara

Tel: 031231705 50/1638

e-posta: Hijran.Yavuzcan@agri.ankara.edu.tr 